\title{
«ISSUES OF ORIENTATION TO THE PROFESSION» (based on the teachings of Eastern thinkers)
}

\author{
${ }^{1}$ Zaretdinova Nesibeli Zaretdinovna \\ ${ }^{1}$ Karakalpak state University named after Berdakh \\ assistant of the Department of social Sciences \\ e-mail: z.nesibeli@karsu.uz
}

\section{ABSTRACT}

This article provides information about education, mastering professions, choosing a profession, as well as Pandu-instructions of great scientists provided by parents to children from families of our Republic. It was noted that the views of Eastern thinkers can be used in the correct formation of professional choice of young people, it is necessary to know one or more types of professions of each adult, to acquaint our children with small types of professions and to solve tasks that should be performed by the state.

Keywords: family, child, youth, profession, professional orientation, choice of profession, sociology. Article Received: 10 August 2020, Revised: 25 October 2020, Accepted: 18 November 2020

Introduction. A profession is a historically established stable form of labor activity that has existed all over the world, in which a person must have certain theoretical knowledge and practical experience, skills, special abilities and important professional qualities. This is an important personality trait that not only determines the specifics of a person's labor activity, but also plays an important role in shaping his views, values, interests, contributes to the determination of a person's social status, ways of self-realization, behavior and more.

Professional education is understood in the broadest sense as a person's intellectual abilities, physical capabilities or fitness, interests and aspirations for other areas, as well as entering the field after receiving education in the field of values and worldviews, becoming mature and experienced personnel. in the old days. Undoubtedly, this is a complex, endless, irreversible important process in which the formation of a personality that effectively uses the path of interest is one of the important problems of our time.

The issues of the professional choice of young people were not only the object of study of modern science, but were also the focus of attention of social thinkers at different stages of historical development. The worldview of oriental thinkers can be used in the correct formation of the career choice of young people. In the East, education and upbringing of youth, vocational training is one of the oldest programs.

Materials and methods. It is worth noting that our people pay great attention to the upbringing of the younger generation, because various proverbs and legends have been collected for centuries and have not lost their significance. For example, "A disciple who is not passed from his master, not a disciple", "A skilled person is not despised," "A young man has less than seventy professions," "Laziness is the threshold of poverty"1 etc. [1,240]. These wise sayings and sayings from ancient times inspired the younger generation of our ancestors to become spiritually and physically perfect people and acquire a unique profession.

In addition to teaching young people, the idea of vocational training also plays an important role in the teachings of oriental thinkers. For example, this is discussed in detail in the works of Abu Nasr al-Farabi [2,223], Abu Raikhan al-Beruni $[3,487]$, Yusuf al-Hajib [4,128], Berdakh [5,39] and others.

The great thinker Abu Nasr al-Farabi shared his thoughts and valuable advice on the profession. According to him, education is a set of knowledge and skills, and upbringing is a set of practical skills, and work is a certain profession, and people who are interested are really interested in this profession $[6,31]$. From such views, it is easy to understand that the profession has always been very necessary for mankind.

In particular, the words of the great thinker Abu RaikhanBeruni: "If you show me your youth, I will tell you what the future of your country will be like"2 $[7,487]$. Youth, as the main subject of sociopolitical, economic, cultural and spiritual renewal of society, has an impact on the processes taking place in society.

Abu Raikhan al-Beruni expresses his very important views on the profession and training in

\footnotetext{
${ }^{1}$ «Ustozdano'zmaganshogird-shogirdemas», «Hunarliodamxorbo'lmaydi», «Yigitkishigayetmishhunaroz», «Dangasalikkambag'allikningostonasi»

${ }^{2}$ Menga yoshlaringizni ko'rsatsangiz davlatingizning ertangi kuni qanday bo'lishini aytib beraman»
} 
the field of human development. He divides the work of each master into types of hard labor: builder, digger, artisan and scientist. It should be noted that special attention to the work of scientists encourages white volunteering. He calls them enlighteners who contribute to the renewal of society. At the same time, he warns that hard workers, miners, underground ore seekers should encourage the work of farmers. The reason is that these workers have proven that they are the backbone of the country. Beruni also thinks about ways and means of vocational training of children and says that children need to be taught to work from an early age [7,517]. The legacy of professional education is relevant and very important for the educational program of this period.

It was also considered essential that every adult in the morning know one or more of the professions of the king and the common citizen. For this reason, celebrities, both wealthy and ordinary, paid attention to ensuring that their children were educated as well as professional while striving to follow such unwritten rules. Beruni emphasizes that in order for a person to be ideal in all respects, he must be educated, as well as hardworking and professional [9 517]. Because from the very beginning of human society, people were forced to live by their labor and profession and had been accepted as the task of life.

According to Abu Ali ibnSina, each child needs to be taught a certain profession. It is believed that if a young man masters a certain profession, uses it in his life and independently provides for his family on the basis of this profession, he should be married to his parents [10, 208]. Through vocational training, young people develop human qualities such as endurance, tolerance, patience, hard work, skill, ability, wisdom.

Yusuf Has Hajib expressed his important views on farmers, shepherds, traders, doctors, scientists who played an important role in the development of society and the well-being of people, and indicated the place of each in society. He highly appreciates the role of farmers and shepherds in socio-economic life and describes their work as the greatest, most noble, sacred [11.99]. At that time, Yusuf Has Hajib's kindness to the masters was not spontaneous. Peace and tranquility of the state, its position in the world, its wealth, well-being of people depended on this category of people. After all, vocational education is a unit of measurement of socio-political, material and cultural development. Apparently, the scientist praises every professional who has contributed to the development of society, and emphasizes the need to value them.

Kaykovus emphasizes the need for a profession along with science in the development of society: your father and mother do not care about it. But you have a name with a profession $[12,173]$. Therefore, the performance glorifies different professions.

Along with the acquisition of knowledge, Saadi indicates how much the profession is higher than a person. "Craft is a hot spring, an endless fortune. If an artisan loses his property, he has no grief. Craftsmen are appreciated wherever he goes and has taken a place in the network of his home. An unskilled person always suffers. He begs." ${ }^{3}[13$ 517]. It is an expression of Saadi's ideas that highlight the greatness of science for humans.

Jami, like Farobi, considers the main duty of young people to get a useful profession [14,33]. He emphasizes that a person cannot do two things, but only engage in a certain profession, master it thoroughly. He prefers to have a profession, to be engaged in it, rather than wealth. Encourages young people to pursue a profession.

Conclusion. As mentioned above, in different periods of historical development, young people were brought up ready to work with a versatile qualification. In a new environment, we consider it a modern requirement to teach young people to draw their own conclusions, take responsibility for the reality and consequences of these conclusions, and focus their personal qualities on professionalism, literacy, social mobility and other relevant competitions.

This means that in the past, values were at the center of important values in society. However, in the current changing social processes and factors, there have been profound changes in the orientation of the young generation towards values, and these were shaped by the structure of career choice. Since the value orientation provides a meaningful description of the subject from an ideal point of view, it is not a sufficient basis for real career choices and interests. In turn, the dynamic description of value orientation embodies the capabilities of human movement. Therefore, in the process of choosing a profession, it is advisable for the subject to focus on his own values from an individual point of view. However, we believe that he must adequately understand his real and potential capabilities.

In conclusion, it should be noted that the choice of a profession in the works of orientalists, the study of ideas about career guidance, their implementation helps the younger generation to make an informed choice of profession. Professional education of children from an early age is one of the main tasks of society. In them,

\footnotetext{
${ }^{3}$ Hunar qaynar buloq, tuganmas davlat. Agar hunarmand molidan mahrum bo'lsa, qayg'usi yo'qdur. Hunarmand qaerga borsa qadrlanadi va uyining to'ridan joy oladi. Hunarsiz odam hamisha mashaqqat chekadi. Tilanchilikqiladi.
} 
professional understanding and imagination serve to enrich knowledge.

\section{References:}

1. Ajdodlaro'giti, hikoyalar, hikmatlar / To'plovchiB.Ahmedov. -Toshkent: «O'qituvchi», 1990. - B. 240

Toshkent:

2.Forobiy Abu Nasr. Fozilodamlarshahri. -

A.Qodiriynomidagixalqmerosinashriyoti, 1993 B. 223.

3.Beruniy Abu Rayxon.

Pamyatnikiminuvshixpokoleniy.-

Toshkent.,1997.T. 1. - S. 487.

4.YusufXosXojib. Qutadg'ubilig.

Toshkent: «Fan», 1972

5.Qoraqalpoqadabiyotidurdonalari.

Berdaxshoirtanlanganasarlar. - Nukus., 2019. - B. 23-39.

Toshkent:

6.Forobiy Abu Nasr. Fozilodamlarshahri. -

A.Qodiriynomidagixalqmerosinashriyoti, 1993 . B. $31 \mathrm{~b}$.

7.Beruniy Abu Rayxon.

Pamyatnikiminuvshixpokoleniy. - Toshkent., 1997.

T. 1. - S. 487.

8.Xoshimov K., Mavlonova R. Pedagogika. - Toshkent., 2001. - B. 517.

9.Irisov A. Abu Ali ibn Sino hayotivaijodiymerosi. - Toshkent: Fan, 1980. - B. 208.

10.Jumaboev

Y..

O'zbekistondafalsafavaahloqiyfikrlartaraqqiyotitari xidan. - Toshkent, 1997- B. 99.

11.Kaykovus. Qobusnoma. -Toshkent: «Meros», 1992. - B. 173.
12.Xoshimov K., Mavlonova

$\mathrm{R}$.

Pedagogika. -Toshkent., 2001. - B. 517.

13.Bilolova

Z.B.

YoshlarningkasbiytushunchalarishakllanishidaShar qmutafakkirlariningpsixologikqarashlaridanfoydala nish // Zamonaviyta'lim / Sovremennoeobrazovanie. 2015. № 10. - B. 33

14.Berdimuratova, A. K., \&Mukhammadiyarova, A. J. (2020). Philosophical and methodological aspects of the interaction of natural environment and man. International Journal of Pharmaceutical Research.

https://doi.org/10.31838/ijpr/2020.12.03.235

15. Pirnazarov, N. (2020). Philosophical analysis of the issue of spirituality. International Journal of Advanced Science and Technology, 29(5).

16. Pirnazarov, N. R. uli. (2020). INFLUENCE

OF VIRTUAL REALITY ON THE SPIRITUALITY OF INFORMATION SOCIETY. EurasianUnionScientists.

https://doi.org/10.31618/esu.24139335.2020.2.71.587

17

Berdimuratova

A, «TileubergenJumamuratovshıǵarmashılıǵffilosofiya liqanalizdińob'ektiretinde», Adamálemi 3 (85) 2020, 19-28

18.

KurmanovAibekPuharbaevich, IbragimovBayniyazAytbaevich.

(2020). Psychological-pedagogical features of studying enterprise (entrepreneurship education in the system of public education). PalArch's Journal of Archaeology of Egypt / Egyptology, 17(7), 1294712950. Retrieved from https://archives.palarch.nl/index.php/jae/article/vie $\underline{w} / 4975$ 